\title{
МУЛЬТИДИСЦИПЛІНАРНИЙ ПІДХІД ДО ІНДИВІДУАЛЬНОЇ РЕАБІЛІТАЦІЇ ПАЦІЄНТІВ ПІСЛЯ ТЯЖКОГО ПЕРЕБІГУ КОРОНАВІРУСНОЇ ХВОРОБИ
}

\author{
О.М. Волянський, А.Ю .Кіх, О.І. Валігура, О.А. Романенко, \\ Т.В. Малецька, В.І. Головатенко
}

\author{
Військово-медичний клінічний лікувально-реабілітаційний центр, м. Ірпінь, Украӥна
}

\begin{abstract}
Мета дослідження: виявити особливості застосування мультидисциплінарного підходу в індивідуальній реабілітації пацієнта після тяжкого перебігу коронавірусної хвороби.

Матеріали та методи. Реабілітаційний процес та оцінку його ефективності розглянуто на окремому прикладі пацієнта А., 61 рік, який був переведений на етап підгострої стаціонарної реабілітацї до пульмонологічного відділення Військово-медичного клінічного лікувально-реабілітаційного центру на 41-й день після початку захворювання на COVID-19. Реабілітаційні заходи цьому пацієнтові проводились протягом 2-х стаціонарних етапів тривалістю 24 і 23 дні з 39-ти денним амбулаторним інтервалом між ними. Оцінка результатів дослідження проводилась при поступленні пацієнта у відділення та перед випискою з відділення при повторній госпіталізації. Для визначення проблем в стані здоров'я пацієнта використовувався категорійний профіль МКФ хворих з захворюванням органів дихання. Дослідження функції зовнішнього дихання проводилось за допомогою спірографа «Spirolab II». Згідно госпітальної шкали (Hospital Anxiety and Depression Scale) визначали ступінь тривоги і депресії. Для поглибленої діагностики емоційного стану пацієнта застосовували опитувальник Спілбергера-Ханіна «Особистісна тривожність» та шкалу Гамільтона для оцінки тривоги (HARS). Оцінювання когнітивних функцій здійснювали за допомогою МоСА-тесту, проби Шульте і тесту запам'ятовування 10 слів (А.Р.Лурія). Сила м'язів визначалась за шестибальною шкалою (L.McPeak, 1996; M.Bейсc, 1986). Рівень спастичності м'язів оцінювався за допомогою модифікованої шкали Ашворта (Bohannon R.W., Smith M.B., 1987). Визначення толерантності до фізичних навантажень проводили за допомогою 6-ти хвилинного тесту ходьби і шкали суб'єктивної оцінки фізичного навантаження (10-ти бальної шкали Борга). Рівень задишки оцінювали за допомогою модифікованої шкали задишки.
\end{abstract}

Результати. В статті розглянуто ефективність мультидисциплінарного підходу в індивідуальній реабілітації пацієнта після тяжкого перебігу коронавірусної хвороби. Показано, що під час роботи в умовах карантину для зменшення ризику зараження коронавірусною хворобою реабілітаційний процес пацієнта був дещо модифікований. Встановлено, що в результаті функціонального оцінювання, проведеного кожним фахівцем команди були визначені основні проблеми категорійного профілю МКФ щодо функції, структур організму, активності і участі пацієнта та оцінено їх ступінь тяжкості. Показано можливість призначення відповідального фахівця за вирішення кожної з проблем. Доведено, що встановлення цілей для вирішення цих проблем і виконання підібраних реабілітаційних інтервенцій для їх досягнення кожним членом команди дозволила відновити втрачені функції організму $i$ активність хворого.

Висновки. Організація реабілітації пацієнта після тяжкого перебігу коронавірусної хвороби шляхом залучення мультидисциплінарної команди фахівців дозволила визначити проблеми щодо функції, структури, активності і участі хворого та призначити відповідального члена команди для вирішення кожної з виявлених проблем. Мультидисциплінарний підхід при проведенні реабілітації хворого з COVID-19 дозволив зменшити рівень тривоги, покращити сон і когнітивні функції, збільшити толерантність до фізичного навантаження і відновити ходьбу пацієнта. Відсутність повного досягнення встановлених цілей при відновленні функцій уваги, емоцій, дихання, толерантності до фізичного навантаження і збереження структурних змін в легенях хворого з COVID-19 вказує на необхідність проведення подальших досліджень для вирішення вказаних проблем.

Ключові слова: COVID-19, SARS-CoV-2, реабілітація, мультидисциплінарна команда.

Вступ. Поява і швидке розповсюдження COVID-19 у всьому світі представила нові виклики військовій медицині України, які пов'язані з необхідністю швидкої діагностики інфекції, викликаної вірусом SARS-CoV-2, наданням спеціалізованої медичної допомоги, а також організації військовослужбовців після захворювання. Стало відомо, що найбільш поширеним клінічним проявом коронавірусної хвороби $\epsilon$ двобічна пневмонія, яка часто приводить до летальних випадків внаслідок дихальної недостатності $[3,24]$. У хворих, які вижили після лікування в умовах реанімації часто розвивається синдром набутої слабкості у відділенні інтенсивної терапії, дисфагія, 
розлади психічного здоров'я та інші когнітивні порушення [15], що потребують подальшої реабілітації даної категорії осіб. Дослідження показали, що проведення реабілітації після важких форм COVID-19 дозволяє пацієнтам повернутися до своїх попередніх занять і зменшує вірогідність довготривалої непрацездатності після декількох днів або тижнів, проведених у відділеннях інтенсивної терапії [18]. Однак, на сьогоднішній день не існує єдиного консенсусу щодо змісту проведення реабілітації пацієнтів після COVID19, а також немає жодних знань про короткочасні та довгострокові наслідки такої реабілітаційної програми [16]. На даний час відомості про епідеміологію, клініку, лікування і реабілітацію пацієнтів 3 коронавірусною хворобою обговорюються фахівцями в режимі реального часу. Так як це захворювання являється новим, інформації про реабілітацію цієї категорії осіб поки що недостатньо.

Мета дослідження полягала у виявленні особливостей мультидисциплінарного застосування індивідуальній реабілітації пацієнта після тяжкого перебігу коронавірусної хвороби.

Матеріали та методи дослідження. Реабілітаційний процес та оцінку його ефективності розглянуто на окремому прикладі пацієнта А., 61 рік, який був переведений на етап підгострої стаціонарної реабілітації до пульмонологічного відділення Військово-медичного клінічного лікувальнореабілітаційного центру (ВМКЛРЦ) на 41-й день після початку захворювання на COVID-19. У відповідності з керівними документами [2], організація реабілітаційного процесу здійснювалась за мультидисциплінарним принципом. Реабілітаційні заходи цьому пацієнтові проводились протягом 2-х стаціонарних етапів тривалістю 24 і 23 дні з 39ти денним амбулаторним інтервалом між ними. Оцінка результатів дослідження проводилась при поступленні пацієнта у відділення та перед випискою 3 відділення при повторній госпіталізації. У відділенні хворому було проведено всебічне клініко-діагностичне обстеження, визначено основні проблемні питання щодо порушення структури і функції, активності та участі, призначено і виконано комплекс реабілітаційних заходів та оцінено їх ефективність. Для визначення проблем у стані здоров'я пацієнта використовувався категорійний профіль Міжнародної класифікації функціонування, обмеження життєдіяльності та здоров'я (МКФ) хворих $з$ захворюванням органів дихання. Фіксація результатів реабілітаційного процесу пацієнта здійснювалась згідно з рекомендаціями МКФ [12]. Реабілітаційні інтервенції цьому хворому проводили у відповідності до рекомендацій [1]. За методикою [10] розробляли індивідуальний план реабілітаційних заходів. Дослідження функції зовнішнього дихання проводилось за допомогою спірографа «Spirolab II». Згідно госпітальної шкали (Hospital Anxiety and Depression Scale) визначали ступінь тривоги i депресії. Для поглибленої діагностики емоційного стану пацієнта застосовували опитувальник Спілбергера-Ханіна «Особистісна тривожність» та шкалу Гамільтона для оцінки тривоги (HARS). Оцінювання когнітивних функцій здійснювали за допомогою МоСА-тесту, проби Шульте і тесту запам'ятовування 10 слів (А.Р.Лурія). Сила м'язів визначалась за шестибальною шкалою (L.McPeak, 1996; М.Вейсc, 1986). Рівень спастичності м'язів оцінювався за допомогою модифікованої шкали Ашворта (Bohannon R.W., Smith M.B., 1987). Визначення толерантності до фізичних навантажень проводили за допомогою 6-ти хвилинного тесту ходьби і шкали субєктивної оцінки фізичного навантаження (10-ти бальної шкали Борга). Рівень задишки оцінювали за допомогою модифікованої шкали задишки.

Результати дослідження та ї обговорення. Під час роботи в умовах карантину для зменшення ризику зараження коронавірусною хворобою реабілітаційний процес пацієнта А. був дещо модифікований. Хворий був розміщений в окрему палату пульмонологічного відділення. Було мінімізовано контакт пацієнта 3 іншими хворими і медичним персоналом та обмежено пересування його в реабілітаційному закладі. Харчування хворого здійснювалось в його палаті. Під час проведення реабілітаційних заходів медичний персонал відділення, а також члени мультидисциплінарної команди використовували засоби індивідуального захисту, керуючись стандартами медичної допомоги «Коронавірусна хвороба (COVID-19)». Індивідуальні заняття з фізичним терапевтом і психологом проводились в межах палати хворого або на подвір'ї реабілітаційного центру.

Організація реабілітаційного процесу цього пацієнта проводилась шляхом залучення мультидисциплінарної команди фахівців. Команду очолював лікар фізичної i реабілітаційної медицини (ФРМ). До складу 
команди також входили: лікар-пульмонолог, лікар внутрішньої медицини, фізичний терапевт, психолог, медична сестра. 3 метою безпечної комунікації між членами команди і пацієнтом перевагу віддавали віртуальному спілкуванню за допомогою технічних засобів зв'язку, аніж взаємодії віч-на-віч.

В перші дні перебування пацієнта у відділенні йому було виконано всебічне клініко-діагностичне i функціональне обстеження. Із анамнезу і даних медичної документації відомо, що пацієнт захворів гостро, коли з'явились скарги на загальну слабкість, ломоту в тілі, озноб, підвищення температури тіла до $37,5^{\circ} \mathrm{C}$. Діагноз було підтверджено позитивним ПЛР тестом на коронавірус SARS-CoV-2. Лікувався у сімейного лікаря. Але у зв'язку з тим, що стан здоров'я хворого погіршувався, на 9-ту добу після початку захворювання був госпіталізований до інфекційного відділення міської лікарні. Лікування в інфекційному відділенні проводилось протягом 32 днів. Пацієнту було проведено курс медикаментозної терапії (лінезолід, цефтріаксон, моксифлоксацин, реосорбілакт, солумедрол, еналазід, амброксол, бісопролол, флуконазол, тіворель, мілдронат, медрол, фленокс), а також інсуфляцію зволоженим киснем. Після виписки 3 інфекційного відділення для проходження реабілітації хворий був госпіталізований у ВМКЛРЦ.

На етапі підгострої реабілітації в хворого не було виявлено ознак загострення коронавірусної хвороби. ПЛР тест на коронавірус SARS-CoV-2 був негативний. B об'єктивному статусі: правильної статури, помірного харчування (IMT=22,6 кг/м²). Шкіра та видимі слизові чисті, звичайного кольору. Периферичні лімфатичні вузли, щитовидна залоза не збільшені. Над легенями перкуторно ясний легеневий звук, аускультативно везикулярне дихання 3 жорстким відтінком, хрипи не вислуховуються. Сатурація кисню 9596\%. Пульс 72 за хвилину, ритмічний. Динаміка AT 120/80-110/70 мм рт.ст. Границі серця: права, верхня - в межах норми, ліва - по лівій середньо-ключичній лінії. Тони серця приглушені, акцент II тону над аортою. Язик чистий, вологий. Живіт м'який, безболісний при пальпації. Печінка, селезінка не збільшені. Постукування в проекції нирок безболісне 3 обох сторін. Фізіологічні відправлення в нормі.

Результати загального клінічного аналізу крові та сечі - без патології. Біохімічний аналіз крові: глюкоза 5,0 ммоль/л, креатинін 95 мкмоль/л, білірубін загальний 13,7 мкмоль/л, АЛТ 120 Од/л, АСТ 63 Од/л, холестерин 5,9 ммоль/л, протромбін 100\%, МНО 1,0. На попередньому етапі лікування було виявлено ознаки гіперкоагуляції крові.

За даними ЕКГ: ритм синусовий регулярний, ЧСС 73 за хвилину, ЕВС відхилена вліво, блокада передньо-верхньої гілки лівої ніжки пучка Гіса. Ультразвукове дослідження нирок, сечового міхура, простати діагностувало наявність конкременту 6 мм та кісти лівої нирки 20х12 мм; збільшення передміхурової залози до 47x38x44 мм. УЗД органів черевної порожнини i щитовидної залози виявило підвищення ехогенності тканин печінки i незначного збільшення розміру щитовидної залози з наявністю множинних гіпоехогенних вузлів. Ультразвукове дослідження екстракраніальних судин - без патології. Результати дослідження функції зовнішнього дихання: фЖЕЛ 60\%, оФВ1 72\%, оФВ1/ЖЕЛ $110 \%$, що свідчить про помірні порушення за рестриктивним типом.

На підставі обстеження пацієнту А. було встановлено клінічний діагноз: Стан після перенесеної коронавірусної хвороби, тяжкого перебігу, двобічної полісегментарної пневмонії. Гіпертонічна хвороба II стадії. IXC, дифузний кардіосклероз. Блокада передньо-верхньої гілки лівої ніжки пучка Гіса. СНI. Кіста лівої нирки. Сечосольовий діатез. Гіперплазія передміхурової залози I ступеня. Хронічний простатит в стадії ремісії. Стеатогепатоз. Вузловий зоб.

3 метою виявлення проблем в стані здоров'я згідно з МКФ пацієнту було проведено функціональне оцінювання. Опитування за допомогою госпітальної шкали тривоги та депресії показало рівень тривоги на 6 балів, а депресії - на 3 бали. Отримані результати вказували на відсутність достовірних ознак тривоги і депресії. Але під час спостереження за хворим було помічено елементи тривожної поведінки та наявність страху. Пацієнт скаржився на відчуття постійного напруження, переривчастий сон, тривожні побоювання щодо свого стану, страх повернення додому i залишення лікувального закладу. Хворий уникав скупчень людей і дуже часто вимірював собі рівень сатурації кисню. Тому нами було застосовано більш поглиблене оцінювання емоційного стану пацієнта. Результати оцінки за шкалою Гамільтона показали 31 бал, що вказувало на наявність вираженого тривожного розладу. Високий рівень тривоги (56 балів) було підтверджено за допомогою 
опитувальника Спілбергера-Ханіна. Результат Монреальської шкали оцінки когнітивних функцій рівнявся 25 балам і було виявлено деяке погіршення пам'яті і уваги хворого. Для більш детальної діагностики застосовували пробу Шульте з середнім показником 77,2 с, що свідчить про помірні порушення уваги. Ступінь впрацьованості рівнялась 0,91, а психологічної стійкості - 0.98. Це вказувало на незначні порушення даних характеристик у хворого. При проведенні тесту Лурія пацієнт зміг відтворити 3-4 слова, що вказувало на незначні порушення пам'яті.

Вже на другий день перебування хворого у відділенні йому було проведено мануальне м'язове тестування, оцінку тонусу м'язів за модифікованою шкалою Ашворта i визначено ступінь рухливості в суглобах за допомогою гоніометра. Результати досліджень показали, що сила, тонус м'язів і рухливість суглобів відповідали нормі. Однак тривале перебування в лікарні привело до появи слабкості при виконанні неважких завдань, швидкої втомлюваності і зниження загальної м'язової витривалості.

При одяганні і роздяганні у пацієнта з'являлась задишка, що відповідало 4-м балам за модифікованою шкалою задишки. Сильна задишка спостерігалась навіть під час повільної ходьби по коридору на 15 м. Пацієнт суб'єктивно оцінював ступінь такого навантаження за шкалою Борга в 6 балів, що відповідало тяжкому рівню навантаження. Хворому було проведено 6-ти хвилинний тест ходьби. Перед дослідженням визначили норму дистанції для цього тесту, яка становила 535 м. Під час першої проби пацієнт пройшов 457 м за 6-ть хвилин. При цьому ходьба супроводжувалась значною задишкою, яка заважала навіть говорити (8 балів за шкалою Борга). На висоті навантаження ЧСС рівнялась 139 ударів за хвилину, а сатурація кисню знижувалась до 86\%. При виконанні цього тесту пацієнт сильно втомився.

Приведені результати досліджень свідчать про значне зниження толерантності хворого до фізичного навантаження після тривалого лікування в інфекційному відділенні. Ще однією з проблем було зниження маси тіла хворого з початку захворювання на 16 кг.

Проведені обстеження показали, що у пацієнта не було жодних ознак обмеження активності в повсякденній життєдіяльності. Він був повністю незалежним від оточуючих. $\begin{array}{ccr}\text { На } & \text { підставі } & \text { результатів } \\ \text { функціонального } & \text { оцінювання } & \text { фахівцями }\end{array}$ команди були визначені основні проблеми категорійного профілю МКФ щодо функції, структур організму, активності і участі пацієнта та оцінено їх ступінь тяжкості (табл.1). Результати проведеного оцінювання дозволили визначити реабілітаційний прогноз. Члени команди прогнозували, що пацієнт зможе покращити толерантність до фізичних навантажень і повернутись до праці. Вказаний реабілітаційний прогноз дозволив сформулювати глобальну ціль реабілітації, ціль програми послуг на даному етапі та дві цілі цього циклу. На засіданні мультидисциплінарної команди було призначено відповідального фахівця за вирішення кожної 3 проблем та підібрано необхідні реабілітаційні втручання для їх вирішення. 3 метою попередження ускладнень i забезпечення безпеки пацієнта перед початком здійснення реабілітаційних заходів були встановлені застереження щодо попередження надмірного підвищення ЧСС, АТ, чД і зниження сатурації кисню під час занять фізичної терапії та попередження інфікування гострими респіраторними захворюванням на фоні отримання глюкокортикоїдної терапії.

Отже, на основі отриманих результатів функціонального обстеження фахівцями команди було розроблено індивідуальний план реабілітації пацієнта. План було розроблено вже на 3-тю добу перебування хворого у відділенні. В подальшому по мірі вирішення проблем в стані здоров'я пацієнта план поновлювався.

Лікар ФРМ разом з фізичним терапевтом, ерготерапевтом і психологом розробили SMART цілі для вирішення кожної $з$ проблем активності і участі пацієнта. Психолог мультидисциплінарної команди щоденно проводила індивідуальні заняття психотерапії. Для цього застосовувались такі методи, як психоедукація, прогресивна релаксація, аутогенне тренування, самонавіювання, реструктуризація думок, пошук ресурсів та опора на них.

Для корекції уваги застосовували таблиці Шульте, червоно-чорні таблиці Горбова-Шульте, паралельний рахунок, рішення логічних завдань, використання зовнішніх засобів компенсації (блокнот, картинки-нагадування). 3 метою покращення пам'яті застосовували методи заучування слів та речень, візуалізації і згадування потрібної інформації. 
Категорійний профіль МКФ та результати реабілітації пацієнта $A ., 61$ рік

\begin{tabular}{|c|c|c|c|c|c|c|c|c|c|c|c|c|c|c|c|c|c|}
\hline \multirow[b]{2}{*}{\begin{tabular}{|l|}
\multicolumn{1}{|c|}{ Цілі } \\
Глобальна ціль (G): \\
Реінтеграція в \\
суспільство через \\
участь, повернення до \\
професійної \\
діяльності
\end{tabular}} & \multicolumn{8}{|c|}{ До реабілітації } & \multicolumn{9}{|c|}{ Після реабілітації } \\
\hline & & & & & & & & & & & & & & & & & \\
\hline \multicolumn{18}{|l|}{$\begin{array}{l}\text { Ціль програми послуг } \\
\text { (SP): Виписка із } \\
\text { лікувального закладу, } \\
\text { повернення додому }\end{array}$} \\
\hline \multicolumn{18}{|l|}{$\begin{array}{l}\text { Ціль циклу 1 (GG1): } \\
\text { Підвищення } \\
\text { толерантності до } \\
\text { бізичних } \\
\text { навантажень } \\
\end{array}$} \\
\hline \multicolumn{18}{|l|}{$\begin{array}{l}\text { Ціль циклу } 2 \text { (GG2): } \\
\text { Покращення } \\
\text { когнітивних функцій, } \\
\text { зменшення тривоги, } \\
\text { нормалізація сну }\end{array}$} \\
\hline \multirow{3}{*}{\begin{tabular}{|l}
\multicolumn{1}{|c|}{ Категорії МКФ } \\
Функції і структури \\
організму, \\
діяльність та участь \\
\end{tabular}} & \multicolumn{8}{|c|}{ Кваліфікатор МКФ } & \multicolumn{9}{|c|}{ Кваліфікатор МКФ } \\
\hline & & & & \multicolumn{5}{|c|}{ проблема } & & & & & \multicolumn{5}{|c|}{ проблема } \\
\hline & & & & 0 & 1 & 2 & 3 & 4 & & & & & 0 & 1 & 2 & 3 & 4 \\
\hline \multicolumn{18}{|l|}{\begin{tabular}{|l|l|}
$b 134$ & Функція сну \\
\end{tabular}} \\
\hline \multicolumn{18}{|l|}{\begin{tabular}{|l|l|} 
b140 & Функція уваги \\
\end{tabular}} \\
\hline \multicolumn{18}{|l|}{\begin{tabular}{|l|l|}
$b 144$ & $\begin{array}{l}\text { Функція } \\
\text { пам'яті }\end{array}$
\end{tabular}} \\
\hline \multicolumn{18}{|l|}{\begin{tabular}{|l|l}
$b 152$ & Функція емоцій \\
\end{tabular}} \\
\hline \multicolumn{18}{|l|}{\begin{tabular}{|l|l|} 
b430 & $\begin{array}{l}\text { Функції } \\
\text { системи крові }\end{array}$ \\
\end{tabular}} \\
\hline \multicolumn{18}{|l|}{\begin{tabular}{|l|l|}
$b 440$ & $\begin{array}{l}\text { Функція } \\
\text { дихання }\end{array}$ \\
\end{tabular}} \\
\hline \begin{tabular}{|l|l|}
$b 455$ & $\begin{array}{l}\text { Функції } \\
\text { толерантност } \\
\text { i до фізичного } \\
\text { навантаження }\end{array}$ \\
\end{tabular} & & & & & & & & & & & & & & & & & \\
\hline \multicolumn{18}{|l|}{\begin{tabular}{|l|l}
$b 460$ & Відчуття, \\
& повязані 3 \\
& функціонування \\
м серцево- \\
судинної $i$ \\
дихальної \\
систем
\end{tabular}} \\
\hline \multicolumn{18}{|l|}{\begin{tabular}{|l|l|}
$b 530$ & Функції \\
& збереження \\
& маси тіла
\end{tabular}} \\
\hline \multicolumn{18}{|l|}{\begin{tabular}{|l|l|}
$b 740$ & Функція \\
& м'язової \\
& витривалості
\end{tabular}} \\
\hline \multicolumn{18}{|l|}{\begin{tabular}{|l|l|} 
s430 & $\begin{array}{l}\text { Структура } \\
\text { дихальної } \\
\text { системи }\end{array}$ \\
\end{tabular}} \\
\hline \multicolumn{18}{|l|}{\begin{tabular}{|l|l|}
$d 450$ & Ходьба \\
\end{tabular}} \\
\hline \multirow[t]{2}{*}{ Фактори середовища } & \multicolumn{3}{|c|}{$\begin{array}{c}\text { Полегшу- } \\
\text { ючий фактор }\end{array}$} & \multicolumn{5}{|c|}{ бар'єр } & & प̆ & $\mathrm{L}^{\prime}$ & & \multicolumn{4}{|c|}{ бар'єр } & \\
\hline & \begin{tabular}{l|l}
+ & + \\
4 & 3
\end{tabular} & $\begin{array}{l}+ \\
2\end{array}$ & $\begin{array}{l}+ \\
1\end{array}$ & 0 & 1 & $\overline{2}$ & 3 & $\overline{4}$ & + & 3 & 2 & 1 & 0 & 1 & 2 & 3 & $\overline{4}$ \\
\hline \multicolumn{18}{|l|}{\begin{tabular}{|c|l} 
e31 & Найближчі \\
р & родичі
\end{tabular}} \\
\hline \begin{tabular}{|c|l} 
e11 & Дихальний \\
5 & $\begin{array}{l}\text { тренажер TRI- } \\
\text { ВALL }\end{array}$
\end{tabular} & & & & & & & & & & & & & & & & & \\
\hline
\end{tabular}

Примітка: Квалібікатор МКФ: визначає ступінь проблем ( $0=$ немає проблеми до $4=$ повна проблема) в компонентах функцій тіла (b), структурах (s) тіла, діяльності та участі (d) і ступінь позитивного (+) або негативного впливу екологічних (e) та особистих факторів (pf). 
Фізичний терапевт мультидисциплінарної команди був відповідальним за вирішення таких проблемних питань в стані здоров'я хворого, як зниження толерантності до фізичного навантаження, зниження м'язової витривалості і порушення ходьби. Для відновлення функціонального стану і посилення роботи дихальних м'язів було підібрано комплекс фізичних вправ для кінцівок і тулуба. Інтенсивність виконання вправ поступово нарощували, але враховували суб'єктивні відчуття пацієнта, які не повинні були перевищувати 4 бали за шкалою задишки і втоми Борга. Критерієм цього рівня відчуття було посилення частоти і глибини дихання, яке дещо заважало розмовляти хворому. Дозовані фізичні навантаження виконувались при постійному контролю ЧСС, АТ, ЧД і рівня сатурації кисню. Вправи припинялись при виникненні задишки, зниження $\mathrm{SaO} 2$ (<95\%), артеріального тиску < 90/60 або > 140/90 мм рт.ст., частоти серцевих скорочень > 100 ударів за хвилину, температури $>37,2^{\circ} \mathrm{C}$, надмірної втоми, болю в грудях, проявів сильного кашлю, запаморочення, серцебиття, пітливості, втрати рівноваги та головного болю.

Важливим елементом фізичної терапії було застосування дихальних вправ. Для тренування м'язів вдиху застосовували діафрагмальне дихання і дихальний тренажер TRI-BALL, який дозволяв дозувати навантаження. Для створення опору під час видиху пацієнт видихав через трубку в стакан з водою.

Порушення ходьби із-за наявності у пацієнта респіраторної недостатності, 3 одного боку, було проблемою, яку необхідно вирішувати. А з іншого боку, дозована ходьба була найбільш оптимальним методом для відновлення фізичної витривалості. Ходьбу відновлювали поступово. Для цього лікарем ФРМ разом 3 фізичним терапевтом було розроблено SMART-цілі. Спочатку для відновлення ходьби встановлювалась така ціль, що пацієнт зможе самостійно пройти по рівній поверхні 100 м і з перешкодами 50 м за 1 тиждень без значних змін ЧСС, АТ, ЧД і сатурації кисню. Наступна ціль була такою: пацієнт зможе самостійно пройти по рівній поверхні 250 м і з перешкодами 100 м за 2 тижні без значних змін ЧСС, АТ, ЧД і сатурації кисню. Далі була наступна ціль: пацієнт зможе самостійно пройти по рівній поверхні 500 м і піднятися та спуститися на другий поверх по східцям за 3 тижні без значних змін ЧСС, АТ, ЧД i сатурації кисню і т.д. Вказані цілі були досягнуті вчасно. Поступове збільшення навантаження дозволило попередити декомпенсацію патологічних процесів серцево-судинної і дихальної систем хворого.

Окрім приведених вище реабілітаційних втручань, пацієнт отримував медикаментозну терапію (медрол, пантопразол, ксарелто, ентерожерміна, мілдронат, гліцесет, еналазідмоно, небівал, дарсіл, саргін, вазопро).

Перед випискою 3 відділення після першого етапу реабілітації було проведено повторне функціональне оцінювання та дано рекомендації щодо самостійного проведення фізичних вправ і дихальної гімнастики в домашніх умовах.

Повторне психологічне оцінювання було проведено хворому наприкінці другого етапу стаціонарної реабілітації. Діагностика за шкалою Гамільтона показала 22 бали, що вказує на наявність середнього рівня тривожного розладу і позитивну динаміку в порівнянні з попередніми даними. Робота 3 таблицями Шульте зайняла у пацієнта: 48 с, 48 c, 57 c, 40 с, 80 с. Середній показник становив 54,6 с. Ступінь впрацьованості - 0,88, а психологічна стійкість - 0,73. Приведені дані вказували на покращення уваги пацієнта під впливом реабілітаційних заходів. Однак значне сповільнення роботи 3 останньою таблицею може свідчити про виснаженість уваги у хворого. Під час тесту Лурія пацієнт зміг відтворити 6-8 слів із 10-ти, що говорить про відновлення його пам'яті. В процесі спостереження за пацієнтом відмічалось покращення його емоційного стану i підвищення толерантності до тривоги. Пацієнт оволодів такими методами самодопомоги, як прогресивна релаксація, аутогенне тренування та реструктуризації думок. Застосування цих методів і покращення свого фізичного стану були запорукою відновлення функції емоцій.

Після проведення реабілітаційних заходів на другому етапі стаціонарної реабілітації спостерігалось значне покращення функціонального стану хворого у вигляді зменшення задишки, яка з'являлась тільки під час швидкої ходьби. При виконанні 6-ти хвилинного тесту ходьби пацієнт зміг пройти 543 м, що відповідало нормативному показнику. А суб'єктивні відчуття навантаження відповідали 3 балам за шкалою Борга. При цьому ЧСС прискорювалась до 107 ударів за хвилину, а сатурація кисню знижувалась до 93\%. В кінці другого етапу 
стаціонарної реабілітації хворий проходив до 6-7 км за день. Отримані результати досліджень свідчать про значне покращення функції толерантності до фізичного навантаження в цього пацієнта. Однак повного відновлення цієї функції не відбулось, що вказує на необхідність проведення тривалої і активної реабілітації в амбулаторних умовах. Перед випискою 3 відділення фізичний терапевт ознайомив хворого 3 переліком і обсягом вправ для самостійного виконання вдома.

Під час проходження реабілітаційних заходів пацієнт отримував дієтичне харчування із збільшенням вмісту білків в щоденному раціоні. Це дозволило повністю відновити втрачену масу тіла хворого.

Перед випискою з відділення хворому було проведено дослідження загального клінічного аналізу крові, сечі, біохімічних показників крові, які були в межах норми. Повторно було оцінено функцію зовнішнього дихання. Отримано такі результати: фЖЕЛ 77\%, оФВ1 94\%, оФВ1/ЖЕЛ 121\%. Як видно 3 приведених даних, показник форсованої життєвої ємкості легень зріс під впливом реабілітаційних заходів на $17 \%$. Це свідчить про покращення еластичності і збільшення частки функціонуючих тканин легенів хворого. Але нормою для даного показника $\epsilon$ значення > 80\%. Тобто, нам не вдалося досягнути повного відновлення функції дихальної системи.

В цей період хворому було виконано МСКТ грудної клітини. За допомогою цього методу виявлено ознаки резидуальних інтерстиціальних змін обох легень більше справа, ймовірно як прояв постзапальних змін із тенденцією до фіброзу, фракційні бронхоектази, одинокий кальцинат верхньої долі правої легені. На попередньому етапі лікування хворому не виконували комп'ютерну томографію органів грудної порожнини. Тому ми не можемо встановити динаміку структурних змін легень цього пацієнта з часом. Йому проводили декілька досліджень рентгенографії грудної порожнини i було діагностовано ознаки двобічної полісегментарної пневмонії.

Зміни значень основних проблемних питань в стані здоров'я пацієнта із наслідками коронавірусної хвороби і відновлення втрачених функцій під впливом реабілітаційних процедур приведено в (табл. 1). Як показано в таблиці, в результаті реабілітаційних заходів було повністю відновлено сон, пам'ять пацієнта, зменшено порушення уваги, проявів тривоги, страхів, покращено функцію дихання, зменшено задишку, значно покращено функцію толерантності до фізичного навантаження, покращено загальну м'язову витривалість, відновлено масу тіла та ходьбу. Однак, поки що не вирішеною проблемою залишаються структурні зміни легень цього пацієнта.

Літературні дані свідчать про те, що довготривалі наслідки ураження легень після COVID-19 поки що невідомі. Нещодавні дослідження показали, що через 100 днів після початку COVID-19 у 41\% пацієнтів зберігались стійкі клінічні симптоми, при цьому частіше всього спостерігалась задишка [19]. Відповідно, у пацієнтів все ще спостерігалось порушення функції легенів. Найбільш часто діагностували зниження дифузної здатності легень (21\%). КТ-дослідження виявили органічну патологію легень у 63\% пацієнтів. Але послідовні подальші оцінювання після 100 днів від початку COVID-19 продемонстрували значне зменшення симптомів та патологічних ознак за даними КТ 3 часом. В іншому дослідженні [5] було показано, що такі симптоми, як втома, задишка, біль в суглобах і біль в грудях все ще часто виявляються навіть через 30 днів після виписки із стаціонару та супроводжуються зниженням якості життя у 44\% хворих на COVID-19.

Новизна захворювання та збільшення використання реабілітаційних послуг пацієнтами COVID-19 посилюють потребу в подальших дослідженнях. Багатонаціональна робоча група фахівців рекомендує мультидисциплінарний підхід 3 використанням моделі легеневої реабілітації, а також з відновленням функції скелетних м'язів і зменшенням психологічних розладів пацієнтів з COVID-19 [11,20]. Однак, ще конкретно не визначені такі питання, як «міра тренувань функції дихання», «міра фізичного навантаження», «комплексна програма легеневої реабілітації» та «харчова підтримка». Крім цього, фахівці вказують, що реабілітація цієї категорії осіб повинна бути інтегрована до заходів запобігання та боротьби з інфекціями, а медичні працівники повинні використовувати засоби індивідуального захисту. Акцент робиться на модифікацію реабілітаційних практик для боротьби 3 інфекцією. Вказується, що для зменшення ризику зараження доцільно мінімізувати контакт пацієнта 3 професіоналами команди, більше 
використовувати віртуальні зустрічі членів команди, розміщувати пацієнтів в окремій палаті, сеанси реабілітації слід робити в межах палати, щоб обмежити пересування пацієнта у реабілітаційному закладі, слід уникати проведення занять фізичної терапії в залах ЛФК. Також треба враховувати той факт, що оцінка функції легень та тестування фізичних навантажень не рідко неможливо виконати в інфекційних хворих. Тренування вправ можливо доведеться починати 3 відносно простих градуйованих функціональних та зміцнювальних вправ, не використовуючи реабілітаційного обладнання.

В роботі [6] також вказується, що реабілітацію пацієнтів після COVID-19 слід проводити в пульмонологічному відділенні. Пацієнти повинні залишатись у своїх кімнатах. Організацію фізичної терапії необхідно здійснювати у вигляді індивідуальних занять. При цьому забороняється проводити групову терапію в реабілітаційних залах

Дослідження [17,23] показали, що в хворих з COVID-19 відбувається значне зниження функції дихальних м'язів, особливо у пацієнтів 3 ожирінням, яке часто недооцінюється лікарями. Тобто, не тільки ураження структури легень $\epsilon$ причиною респіраторної недостатності, а й порушення функції дихальних м'язів. Було доведено, що тренування дихальних м'язів сприяло збільшенню сили, фізичної здатності i товщини м'язів діафрагми, що в результаті зменшувало задишку. В інших дослідженнях було показано, що атрофію і дисфункцію дихальних м'язів може посилювати прийом кортикостероїдів [8]. Ми врахували результати цих літературних даних при проведенні реабілітації пацієнту А., оскільки він тривало отримував глюкокортикоїдний препарат медрол.

В підгострій реабілітації доцільно включати вправи на тренування м'язів під час вдиху. Для цього застосовують вправи 3 глибоким, повільним диханням, 3 розширенням рудної клітини (з підняттям плечей), діафрагмальне дихання, мобілізацію дихальних м'язів, техніки очищення дихальних шляхів (за необхідності) та пристрої з позитивним тиском на видиху [25]. Однак, під час проведення процедур 3 респіраторної реабілітації необхідно зберігати обережність, щоб уникнути перевантаження дихальної системи і спричинення дистресу $[7,21]$.
Вже проведено перші доказові дослідження. Показано, що шеститижнева реабілітація може покращити дихальну функцію, якість життя та зменшити тривожність у пацієнтів похилого віку з COVID19 , але вона не мала значного покращення щодо депресії у літніх людей [14]. Автори цієї роботи вперше кількісно стандартизували тренування 3 дихальної реабілітації, які проводили щодня по 10 хвилин 2 рази на день.

На сьогодні відсутні детальні знання про прогноз після COVID-19. Тому до отримання цієї інформації при проведенні реабілітації пацієнтів після перенесеного захворювання необхідно враховувати можливість довгострокового відновлення пошкоджених тканин організму людини, яке триватиме протягом 12-24 місяців [222]. Одним 3 основних компонентів серцевої та легеневої реабілітації $є$ фізичні вправи, які сприяють збільшенню сили м'язів і покращенню функції серцевої і дихальної систем. 3 метою тестування фізичних характеристик і оцінки ефективності реабілітації рекомендується тест 6-ти хвилинної ходьби. При цьому ступінь задишки реєструють за допомогою модифікованої шкали Борга (0-10 балів).

Хворі, які вижили після перебування в реанімації переживають емоційний стрес, який пов'язаний з соціальною ізоляцією від сім'ї та друзів на тривалий період часу із-за карантинних обмежень. В них було діагностовано ознаки тривожності (34\%), депресії (33\%) та посттравматичного стресового розладу (19\%) [9]. Отримані результати майже співпадають 3 іншими авторами [4], які виявили депресію у 25\% пацієнтів 3 COVID-19. Значна частота тривожних і депресивних розладів в цієї категорії осіб вказує на необхідність проведення психотерапії в комплексі реабілітаційних заходів [13]. Треба сприяти спілкуванню пацієнтів з членами сім'ї та друзями. Отже, психо-соціальна підтримка важливий компонент втручання. Він включає такі методи, як когнітивно-поведінкова терапія і мотиваційне стимулювання. Під час реабілітації важливо проводити інформування пацієнта і членів його родини про хворобу, її лікування та прогноз.

Останнім етапом реабілітації $є$ оцінка їі ефективності. Вона дозволяє відповісти на запитання: «чи були досягнуті цілі?, чи можна пацієнта виписати 3 відділення?, чи $\epsilon$ необхідність в продовженні реабілітаційних заходів в амбулаторних умовах?». 


\section{Висновки}

1. Організація реабілітації пацієнта після тяжкого перебігу коронавірусної хвороби шляхом залучення мультидисциплінарної команди фахівців дозволила визначити проблеми щодо функції, структури, активності i участі хворого та призначити відповідального члена команди для вирішення кожної з виявлених проблем.

2. Мультидисциплінарний підхід при проведенні реабілітації хворого з COVID-19 дозволив зменшити рівень тривоги, покращити сон і когнітивні функції, збільшити толерантність до фізичного навантаження i

\section{References}

1. On approval of the protocol for providing rehabilitation care to patients with coronavirus disease (COVID-19) and convalescents: Order of the Ministry of Health of Ukraine dated 20.04.2021 №771. URL: https://moz.gov.ua/article/ministry-mandates/nakazmoz-ukraini-vid-20042021--771-pro-zatverdzhennjaprotokolu-nadannja-reabilitacijnoi-dopomogi-

pacientam-z-koronavirusnoju-hvoroboju--covid-19-tarekonvalescentam

2. On rehabilitation in the field of health care: Law of Ukraine of 03.12.2020 №1053-IX. URL: https://zakon.rada.gov.ua/laws/show/1053-20\#Text

3. Bchetnia M., Girard C., Duchaine C., Laprise C. (2020). The outbreak of the novel severe acute respiratory syndrome coronavirus 2 (SARS-CoV-2): A review of the current global status. Journal of Infection and Public Health, 13(11), 1601-1610. https://doi.org/10.1016/j.jiph.2020.07.011.

4. Bueno-Notivol J., Gracia-García P., Olaya B. (2021). Prevalence of depression during the COVID-19 outbreak: A meta-analysis of community-based studies. International Journal of Clinical and Health Psychology, 21(1). https://doi.org/10.1016/j.ijchp.2020.07.007.

5. Carfi A., Bernabei R., Landi F. et al. (2020). Persistent Symptoms in Patients After Acute COVID-19. JAMA, 324(6),

603-605.

https://doi.org/10.1001/jama.2020.12603.

6. Chang MC, Park D. (2020). How should rehabilitative departments of hospitals prepare for coronavirus disease 2019?. American journal of physical medicine \& rehabilitation., 99(6), 475-476. https://doi.org/10.1097/phm.0000000000001428.

7. Chinese Association of Rehabilitation Medicine, Respiratory Rehabilitation Committee of Chinese Association of Rehabilitation Medicine, Cardiopulmonary Rehabilitation Group of Chinese Society of Physicai MedicineRehabilitation. Recommendations for respiratory rehabilitation of COVID-19 in adult. (2020). Zhonghua Jie He He Hu Xi Za Zhi, 12;43(4),

308-314. https://doi.org/10.3760/cma.j.cn112147-2020022800206 .

8. Derde S, Hermans G, Derese I. et al. (2012). Muscle atrophy and preferential loss of myosin in prolonged відновити ходьбу пацієнта.

3. Відсутність повного досягнення встановлених цілей при відновленні функцій уваги, емоцій, дихання, толерантності до фізичного навантаження i збереження структурних змін в легенях хворого з COVID-19 вказує на необхідність проведення подальших досліджень для вирішення вказаних проблем.

\section{Перспективи подальших досліджень.}

У подальшій роботі плануються дослідження для визначення оптимальної кількості, обсягу і тривалості респіраторної реабілітації, фізичної терапії і психотерапії пацієнтів після тяжкого перебігу коронавірусної хвороби

critically ill patients. Crit Care Med., 40(1), 79-89. https://doi.org/ 10.1097/CCM.0b013e31822d7c18.

9. Dijkstra-Kersten S., Kok L., Kerckhoffs M. (2020). Neuropsychiatric outcome in subgroups of Intensive Care Unit survivors: Implications for after-care. J Crit Care, 55, 171-176. https://doi.org/ 10.1016/j.jcrc.2019.11.006.

10.European Physical and Rehabilitation Medicine Bodies Alliance (2018). White Book on Physical and Rehabilitation Medicine in Europe. Introductions, Executive Summary, and Methodology. European journal of physical and ehabilitation medicine, 54(2), 125-155. https://doi.org/10.23736/S1973-9087.18.05143-2.

11. Glöckl R., Buhr-Schinner H., Koczulla A. R. et al. (2020) [Recommendations from the German Respiratory Society for Pulmonary Rehabilitation in Patients with COVID-19]. Pneumologie, 74(8), 496-504. https://doi.org/ 10.1055/a-1193-9315.

12. ICF research branch. Available from: www.icfresearch-branch.org/download/category/17-icf-basedcase-studies.

13. Kho M, Brooks D, Namasivayam-MacDonald A. (2020). Rehabilitation for Patients with COVID-19: Guidance for Occupational Therapists, Physical Therapists, Speech-Language Pathologists, and Assistants. McMaster School of Rehabilitation Science URL. Available from: https://srsmcmaster.ca/wp-

content/uploads/2020/04/Rehabilitation-for-Patientswith-COVID-19-Apr-08-2020.pdf.

14. Liu K, Zhang W, Yang Y, et al. (2020). Respiratory rehabilitation in elderly patients with COVID-19: A randomized controlled study. Complement Ther Clin, 39:101166. https://doi.org/10.1016/j.ctcp.2020.10116 6.

15. Pan American Health Organisation. Rehabilitation considerations during the COVID-19 outbreak. (2020). 26 Apr. (last accessed 24 June 2020). Available from https://iris.paho.org/bitstream/handle/10665.2/5203 5/NMHMHCOVID19200010_eng.pdf?sequence=6\&isAll owed $=$. .

16. Rutsch, M., Frommhold, J., Buhr-Schinner, H. et al. (2021). Study protocol medical rehabilitation after COVID-19 disease: an observational study with a 
comparison group with obstructive airway disease. Re_Co. BMC Health Serv Res, 21, 373. https://doi.org/10.1186/s12913-021-06378-4.

17. Severin R, Arena R, Lavie CJ. et al. (2020). Respiratory Muscle Performance Screening for Infectious Disease Management Following COVID-19: A Highly Pressurized Situation. Am J Med,133(9), 10251032. https://doi.org/10.1016/j.amjmed.2020.04.003.

18. Sheehy LM. (2020). Considerations for postacute rehabilitation for survivors of COVID-19. JMIR public health and surveillance, 6(2):e19462. https://doi.org/10.2196/19462.

19. Sonnweber T., Sahanic S., Pizzini A. et al. (2021). Cardiopulmonary recovery after COVID-19: an observational prospective multicentre trial. European Respiratory Journal, 57: 2003481. https://doi.org/10.1183/13993003.03481-2020.

20. Spruit M.A., Holland A. E., Singh S.J. (2020). COVID-19: interim guidance on rehabilitation in the hospital and post-hospital phase from a European Respiratory Society- and American Thoracic Societycoordinated international task force. Eur Respir J., 56(6): 2002197. https://doi.org/ 10.1183/13993003.021972020.

21. Vitacca M, Carone M, Clini E, et al. (2020). L'Associazione Riabilitatori dell'Insufficienza
Respiratoria. Joint statement on the role of respiratory rehabilitation in the COVID-19 crisis: the Italian position paper

from: URL. Available content/uploads/2020/03/Joint-statement-roleRR_COVID_19_E_Clini.pdf.

22. Wade D.T. (2020). Rehabilitation after COVID-19: an evidence-based approach. Clin Med (Lond), 20(4), 359-365. https://doi.org/ 10.7861/clinmed.20200353.

23. Wischmeyer PE, San-Millan I. (2015). Winning the war against ICU-acquired weakness: new innovations in nutrition and exercise physiology. Crit Care, 19 (Suppl 3): S6. https://doi.org/10.1186/cc14724.

24.Yafei Wang, Ying Zhou, Zhen Yang, Dongping Xia , Yi Hu , Shuang Geng.(2020). Clinical Characteristics of Patients with Severe Pneumonia Caused by the SARSCoV-2 in Wuhan, China. Respiration, 99(8), 649-657. https://doi.org/10.1159/000507940.

25.Zhao H, Xie Y, Wang C. (2020). Recommendations for respiratory rehabilitation in adults with COVID-19. Chin Med J (Engl), 133(13), 15951602. https://doi.org/10.1097/CM9.00000000000008 48.

\title{
МУЛЬТИДИСЦИПЛИНАРНЫЙ ПОДХОД К ИНДИВИДУАЛЬНОЙ РЕАБИЛИТАЦИИ ПАЦИЕНТОВ ПОСЛЕ ТЯЖЕЛОГО ТЕЧЕНИЯ КОРОНАВИРУСНОЙ БОЛЕЗНИ
}

\author{
О.М. Волянский, А.Ю.Ких, Е.И.Валигура, О.А.Романенко, Т.В.Малецкая, В.И.Головатенко
}

Военно-медищинский клинический лечебно-реабилитационный центр, г. Ирпень, Украина

Цель исследования: выявить особенности применения мультидисциплинарного подхода в индивидуальной реабилитации пациента после тяжелого течения коронавирусной болезни.

Материалы и методы. Реабилитационный процесс и оценку его эффективности рассмотрен на отдельном примере пациента А., 61 год, который был переведен на этап подострой стационарной реабилитации в пульмонологическое отделение Военно-медицинского клинического лечебнореабилитационного центра на 41-й день после начала заболевания COVID-19. Реабилитационные мероприятия этом пациенту проводились в течение 2-х стационарных этапов продолжительностью 24 и 23 дня с 39-ти дневным амбулаторным интервалом между ними. Оценка результатов исследования проводилась при поступлении пациента в отделение и перед выпиской из отделения при повторной госпитализации. Для определения проблем в состоянии здоровья пациента использовался категорийный профиль МКФ больных с заболеванием органов дыхания. Исследование функции внешнего дыхания проводилось с помощью спирографа «Spirolab II». Согласно госпитальной шкалы (Hospital Anxiety and Depression Scale) определяли степень тревоги и депрессии. Для углубленной диагностики эмоционального состояния пациента применяли опросник Спилбергера-Ханина «Личностная тревожность» и шкалу Гамильтона для оценки тревоги (HARS). Оценка когнитивных функций осуществляли с помощью МоСатеста, пробы Шульте и теста запоминания 10 слов (А.Р.Лурия). Сила мыши определялась по шестибалльной шкале (L.McPeak, 1996; M.Вейсc, 1986). Уровень спастичности мышц оценивался с помощью модифицированной шкалы Ашворта (Bohannon R.W., Smith M.B., 1987). Определение толерантности к физическим нагрузкам проводили с помощью 6-ти минутного теста ходьбы и шкалы субъективной оценки физической нагрузки (10-ти балльной шкалы Борга). Уровень одышки оценивали с помощью модифицированной шкалы одышки.

Результаты. $B$ статье рассмотрена эффективность мультидисциплинарного подхода в индивидуальной реабилитации пациента после тяжелого течения коронавирусной болезни. Показано, что при работе в условиях карантина для уменьшения риска заражения коронавирусной болезнью реабилитационный процесс пациента был несколько модифицирован. Установлено, что в результате функционального оценивания, проведенного каждым специалистом команды были определены основные проблемы категорийного профиля МКФ по функции, структуре организма, активности и участия пациента и оценена их степень тяжести. Показана возможность назначения ответственного 
специалиста за решение каждой из проблем. Доказано, что установление целей для решения этих проблем и выполнение подобранных реабилитационных интервенций для их достижения каждым членом команды позволила восстановить утраченные функции организма и активность больного.

Выводы. Организация реабилитации пациента после тяжелого течения коронавирусной болезни путем привлечения мультидисциплинарной команды специалистов позволила определить проблемы по функции, структуры, активности и участия больного и назначить ответственного члена команды для решения каждой из обнаруженных проблем. Мультидисциплинарный подход при проведении реабилитации больного с COVID-19 позволил уменьшить уровень тревоги, улучшить сон и когнитивные функции, увеличить толерантность к физической нагрузке и восстановить ходьбу пациента. Отсутствие полного достижения поставленных целей при восстановлении функций внимания, эмоций, дыхания, толерантности к физической нагрузке и сохранения структурных изменений в легких больного с COVID-19 указывает на необходимость проведения дальнейших исследований для решения указанных проблем.

Ключевые слова: COVID-19, SARS-CoV-2, реабилитация, мультидисциплинарная команда.

\title{
MULTIDISCIPLINARY APPROACH TO INDIVIDUAL REHABILITATION OF PATIENTS AFTER SEVERE CORONAVIRUS DISEASE
}

\section{O.M. Volianskyi, A.Yu. Kikh, E.I. Valigura, O.A. Romanenko, T.V. Maletskaya, V.I. Golovatenko}

\author{
Military Medical Clinical Treatment and Rehabilitation Center, Irpin, Ukraine
}

The purpose: to identify the features of the multidisciplinary approach in the individual rehabilitation of the patient after a severe coronavirus disease.

Materials and methods. The rehabilitation process and evaluation of its effectiveness were considered on a separate example of patient $A$., 61 years old, who was transferred to the stage of subacute inpatient rehabilitation to the pulmonology department of the Military Medical Clinical Treatment and Rehabilitation Center on the 41st day after COVID-19. Rehabilitation measures for this patient were performed during 2 inpatient stages lasting 24 and 23 days with a 39-day outpatient interval between them. The results of the study were evaluated when the patient was admitted to the ward and before discharge from the ward during re-hospitalization. The categorical profile of the ICF of patients with respiratory disease was used to determine the patient's health problems. The study of the function of external respiration was performed using a spirograph "Spirolab II". According to the Hospital Anxiety and Depression Scale, the degree of anxiety and depression was determined. The Spielberger-Khanin Personal Anxiety Questionnaire and the Hamilton Anxiety Rating Scale (HARS) were used to provide an in-depth diagnosis of the patient's emotional state. Cognitive function was assessed using the MoSA test, the Schulte test, and the 10-word memorization test (AR Luria). Muscle strength was determined on a six-point scale (L. McPeak, 1996; M. Weiss, 1986). The level of muscle spasticity was assessed using a modified Ashworth scale (Bohannon R.W., Smith M.B., 1987). Determination of exercise tolerance was performed using a 6-minute walk test and a scale of subjective assessment of physical activity (10-point Borg scale). The level of shortness of breath was assessed using a modified shortness of breath scale.

Results. The article considers the effectiveness of a multidisciplinary approach in the individual rehabilitation of a patient after a severe coronavirus disease. It has been shown that the patient's rehabilitation process was slightly modified during quarantine work to reduce the risk of coronavirus infection. It was found that as a result offunctional assessment conducted by each team specialist, the main problems of the categorical profile of IFF in terms of function, body structures, activity and participation of the patient were identified and their severity was assessed. The possibility of appointing a responsible specialist for solving each of the problems is shown. It is proved that setting goals to solve these problems and performing selected rehabilitation interventions to achieve them by each team member allowed to restore the lost body functions and activity of the patient.

Conclusions. The organization of rehabilitation of the patient after a severe coronavirus disease by involving a multidisciplinary team of specialists allowed to identify problems in terms of function, structure, activity and participation of the patient and appoint a responsible team member to address each of the identified problems. $A$ multidisciplinary approach in the rehabilitation of a patient with COVID-19 has reduced anxiety, improved sleep and cognitive function, increased exercise tolerance and restored the patient's gait. The lack of full achievement of the established goals in the restoration of attention, emotions, respiration, exercise tolerance and preservation of structural changes in the lungs of a patient with COVID-19 indicates the need for further research to address these issues.

Key words: COVID-19, SARS-CoV-2, rehabilitation, multidisciplinary team.

Конфлікт інтересів: відсутній.

Conflicts of interest: authors have no conflict of interest to declare. 


\section{Відомості про авторів:}

Волянський O.M. ${ }^{\mathrm{A}, \mathrm{D}, \mathrm{E}, \mathrm{F}}$ - полковник медичної служби, канд. мед. наук, начальник клініки (реабілітації, профпатології та нетрадиційних методів лікування) Військово-медичного клінічного лікувально-реабілітаційного центру, м. Ірпінь.

Кіх А.Ю. ${ }^{\mathrm{A}, \mathrm{D}, \mathrm{F}}$ - полковник медичної служби, канд. мед. наук, начальник Військово-медичного клінічного лікувально-реабілітаційного центру, м. Ірпінь.

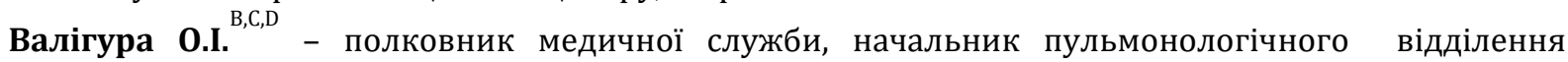
Військово-медичного клінічного лікувально-реабілітаційного центру, м. Ірпінь.

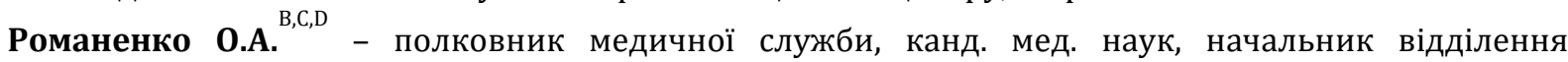
(реабілітації та професійної патології) Військово-медичного клінічного лікувально-реабілітаційного центру, м. Ірпінь. м. Ірпінь.

Малецька Т.В. ${ }^{\text {B, }}$ - психолог Військово-медичного клінічного лікувально-реабілітаційного центру,

Головатенко В.І. ${ }^{\text {в,С }}$ - спеціаліст з фізичної реабілітації Військово-медичного клінічного лікувальнореабілітаційного центру, м. Ірпінь.

$A$ - концепція та дизайн дослідження; B - збір даних; $C$ - аналіз та інтерпретація даних;

$D$ - написання статmi; $E$ - редагування статmi; $F$ - остаточне затвердження статті

Сведения об авторах:

Волянский А.Н., - полковник медицинской службы, канд. мед. наук, начальник клиники (реабилитации, профпатологии и нетрадиционных методов лечения) Военно-медицинского клинического лечебно-реабилитационного центра, г. Ирпень.

Ких А.Ю., - полковник медицинской службы, канд. мед. наук, начальник Военно-медицинского клинического лечебно-реабилитационного центра, г. Ирпень.

Валигура Е.И., - полковник медицинской службы, начальник пульмонологического отделения Военно-медицинского клинического лечебно-реабилитационного центра, г. Ирпень.

Романенко О.А., - полковник медицинской службы, канд. мед. наук, начальник отделения (реабилитации и профпатологии) Военно-медицинского клинического лечебно-реабилитационного центра, г. Ирпень.

Малецкая Т.В., - психолог Военно-медицинского клинического лечебно-реабилитационного центра, г. Ирпень.

Головатенко В.И., - специалист по физической реабилитации Военно-медицинского клинического лечебно-реабилитационного центра, г. Ирпень.

\section{Information about authors:}

Volianskyi O.M. ${ }^{\mathrm{A}, \mathrm{C}, \mathrm{D}, \mathrm{E}, \mathrm{F}}$ - Col. MS, MD, PhD, Head of the clinic (rehabilitation, occupational pathology and alternative methods of treatment) of the Military Medical Clinical Treatment \& Rehabilitation Center, Irpin. Email: 333doctor333@ukr.net,

Kikh A. Yu. ${ }^{\mathrm{A}, \mathrm{E}, \mathrm{F}}$ - Col. MS, MD, PhD, Head of the Military Medical Clinical Treatment \& Rehabilitation Center, Irpin.

Valigura E.I., $^{\mathrm{B}, \mathrm{C}, \mathrm{D}}$ - Col. MD, Head of the pulmonary department of the Military Medical Clinical Treatment \& Rehabilitation Center, Irpin.

Romanenko O.A., ${ }^{\mathrm{B}, \mathrm{C}, \mathrm{D}}$ - Col. MS, MD, PhD, Head of the department (rehabilitation and occupational pathology) of the Military Medical Clinical Treatment \& Rehabilitation Center, Irpin.

Maletskaya T.V., ${ }^{\text {B,C }}$ - psychologist of the Military Medical Clinical Treatment \& Rehabilitation Center, Irpin.

Golovatenko V.I. ${ }^{\text {B,C }}$ - physical therapist of the Military Medical Clinical Treatment \& Rehabilitation Center, Irpin.

$A$ - research concept and design; $B$ - collection and/or assembly of data; $C$ - data analysis and interpretation; $D$ - writing the article; $E$-critical revision of the article; $F$ - final approval of the article.

Адреса для листування: вул. 11 лінія, буд. 1, м. Ірпінь 08203 